\title{
Preharvest Applications of Chitosan, Salicylic Acid, and Calcium Chloride Have a Synergistic Effect on Quality and Storability of Date Palm Fruit (Phoenix dactylifera L.)
}

\author{
Zienab F.R. Ahmed and Navjot Kaur \\ Integrative Agriculture Department, College of Agriculture and Veterinary \\ Medicine, United Arab Emirates University, Al Ain 15551, United Arab Emirates \\ Sajid Maqsood \\ Food Science Department, College of Agriculture and Veterinary Medicine, \\ United Arab Emirates University, Al Ain 15551, United Arab Emirates
}

Guillermo Schmeda-Hirschmann

Institute of Chemistry of Natural Resources, University of Talca, Casilla 747, Talca, Chile

Additional index words. Khenizi, postharvest, storage, chitosan, antioxidant

\begin{abstract}
The 'Khenizi' date palm is one of the most recognized date palm cultivars. It is commonly consumed at the Bisr, Rutab, and Tamr stages of ripening; however, the fruit has a short shelf/storage life at this stage of maturity even with refrigeration. Preharvest application of a natural elicitor chitosan $(\mathrm{Ch})$ has been reported to have positive influences on quality and shelf life of many fruits; however, synergetic effects of Chand other natural elicitors have not been investigated. Therefore, this study aimed to investigate the synergistic effect of preharvest spray treatments with $\mathrm{Ch} 1 \%$ in combination with calcium chloride (Ca) 3\% and salicylic acid (SA) 2 mm on 'Khenizi' date fruit quality and storage life. Fruit quality parameters, including physical and physiochemical characteristics, phytochemical content, and bioactive properties, were determined at harvest time and during cold storage at $2{ }^{\circ} \mathrm{C}$ for 60 days for 2 months. Our results revealed that a combination of these elicitors had significantly influenced the fruit quality during storage compared with control. For instance, $\mathrm{Ch}+\mathrm{SA}$ and $\mathrm{Ch}+\mathrm{Ca}+\mathrm{SA}$ treatments improved total phenolic content (TPC), and the antioxidant activity at harvest and at specific times during the postharvest storage period. Furthermore, $\mathrm{Ch}+\mathrm{SA}+\mathrm{Ca}$ treatment significantly delayed senescence in treated fruits during cold storage for $\mathbf{4 5}$ days as compared with other treatments and the control. In addition, $\mathrm{Ch}+\mathrm{Ca}$-treated fruits had the lowest weight loss after 45 days of cold storage. $\mathrm{Ch}+\mathrm{SA}$ treatment had the lowest microbial counts as compared with other treatments, including the control. The significance of this study is that it provides evidence that a combination of these elicitors has the potential to improve fruit quality at harvest, as well as during postharvest storage Future studies should be directed to fine tune the concentrations and combinations that may have commercial applications.
\end{abstract}

Date palm (Phoenix dactylifera $\mathrm{L}$.) is one of the most successful fruiting trees in semiarid and arid areas around the world, and it is regarded as a significant subsistence crop (Mohamed et al., 2014). Date is the most popular fruit consumed in the Middle East regions (Awad et al., 2011), and contains considerable amounts of essential nutrients, vitamins and minerals, carbohydrates, and

Received for publication 30 Nov. 2021. Accepted for publication 15 Dec. 2021.

Published online 1 February 2022.

This research was funded by United Arab Emirates University, grant number G00003332.

Z.F.R.A. is the corresponding author. E-mail: Zienab.ahmed@uaeu.ac.ae.

This is an open access article distributed under the CC BY-NC-ND license (https://creativecommons. org/licenses/by-nc-nd/4.0/). dietary fibers, antioxidants, and phenolic compounds (Al-Mssallem et al., 2020; AlShwyeh, 2019; Bentrad and Hamida-Ferhat, 2020; Vayalil, 2012, 2013).

Date palm fruit develop and ripen in five distinct stages known by their Arabic terms; Hababouk, Kimri, Khalal or Bisr, Rutab, and Tamer (Al-Qurashi and Awad, 2011). In terms of moisture content, date fruits can be classified into three groups: soft, semi-dry, and dry. The fruit are generally harvested and introduced to the market at three stages; Bisr (full-size, crunchy, colored, and mostly edible), Rutab (soft and brown), and Tamer (hazel to dark brown, wrinkled, raisin-like dry fruit). Depending on climatic conditions, cultivar characteristics, customer desires, and market demands, the fruits are harvested (Mohamed et al., 2014).
'Khenizi' (also known as khenaizy) is a commercially recognized date cultivar that had been grown in the Arabian countries for decades (Aleid and Saikhan, 2017). The flowering of 'Khenizi' starts in early February, and the harvesting period begins in late June. The fruit has an inverted oval shape with a bulge at the top and dark red color at the Bisr maturity stage, which fades to black at the Rutab and Tamer stages. Because of its high tannin content, 'Khenizi' is consumed at late stage of maturity; Rutab and Tamr (Aleid and Saikhan, 2017).

Date palm fruit is a climacteric fruit that ripens quickly to its subsequent soft stage (Rutab) and loses its marketability in a few days (Ahmed et al., 2021a; Mohamed et al., 2014). These changes are caused by the increased respiration rate in living tissues, which leads to an increase in metabolic rate and, eventually, fruit senescence (Abu-Shama et al., 2020; Ahmed and Palta, 2015). Therefore, slowing the ripening process is a critical need for improving the shelf life and marketability of 'Khenizi' date fruit.

Cold storage, Modified Atmosphere Packaging, and Controlled Atmosphere Storage (CA) have been used to minimize quality changes in date palm fruit during storage (Aleid and Saikhan, 2017; Alhamdan et al., 2015; Alsawmahi et al., 2018). Natural elicitors, such as $\mathrm{Ch}, \mathrm{SA}$, and $\mathrm{Ca}$, had also been reported to stimulate physiological adaptations and defensive responses in plants (Baenas et al., 2014). The mechanism by which elicitors exert their effects involves triggering the synthesis of phytochemical compounds, enhancing the production of particular antioxidant enzymes, and reducing the production of ethylene in vegetables and fruits (Baenas et al., 2014; Romanazzi et al., 2018; RuizGarcía and Gómez-Plaza, 2013; Xylia et al., 2021).

Chitosan is one of the most recognized natural elicitors because of its antibacterial, eliciting, and film-forming properties (Baenas et al., 2014; Maan et al., 2021; Moreno-Escamilla et al., 2018; Romanazzi et al., 2018). Pre- and postharvest studies have indicated the positive effects of Chapplication on the quality and shelf life of several fruit crops (Abd Elwahab et al., 2019; Abu-Shama et al., 2020; Ahmed et al., 2021a; Rahman et al., 2018; Romanazzi et al., 2013; Sharif et al., 2018; Shen and Yang, 2017). Another natural elicitor is SA, which is a simple phenolic phytohormone with various roles in plant growth and developmental processes. Pre/ postharvest treatments with SA can dramatically enhance the quality and shelf life, and prevent deterioration in many fruits (Ahmed et al., 2021b; Chen et al., 2020; Gomes et al., 2021; Luo et al., 2011; Mohamed et al., 2014; Sayyari et al., 2009; Zhang et al., 2003). Moreover, $\mathrm{Ch}, \mathrm{SA}$, and $\mathrm{Ca}$ are wellknown natural elicitors that have an important role in the physiology of plant tissue (Ahmed and Palta, 2017). Calcium has been reported to play a vital role in retarding tissue softening and delaying ripening (Atia et al., 2018; Irfan et al., 2013; Sohail et al., 2015). 
The use of $\mathrm{Ca}$ after the fruit has been harvested maintains cell turgor, membrane integrity, and tissue firmness, and delays membrane lipid catabolism, therefore extending storage life of fresh fruits (Ahmed and Palta 2017; Atia et al., 2018).

To the best of our knowledge, reports on the effects of natural elicitors, such as $\mathrm{Ch}$, $\mathrm{SA}$, and $\mathrm{Ca}$, or their synergistic effects on date fruit are limited. Therefore, the objective of this study was to investigate the synergistic effect of preharvest spray application of Chin conjunction with SA and $\mathrm{Ca}$ on 'Khenizi' date palm fruit quality and storability.

\section{Material and Methods}

\section{Plant material and sampling}

Six uniform of 'Khenizi' date palm trees (Phoenix dactylifera L.) were randomly selected at the experimental farm of the College of Agriculture and Veterinary Medicine, located in the Al Foah region, Al Ain, United Arab Emirates, latitude and longitude coordinates of $24.2191^{\circ} \mathrm{N}$ and $55.7146^{\circ} \mathrm{E}$. The trees were 20 years old growing in a sandy loam soil, drip irrigated, and receiving regular agricultural practices. Palm trees were pruned to keep the leaf-to-bunch ratio at $8: 1$, and the number of bunches per palm was adjusted to eight (as a best practice for a 20-year-old palm under $\mathrm{Al}$ Ain region conditions). The experiment had a complete random design with six replicates (palms); each palm received seven different treatments (one treatment per bunch). Each treatment was sprayed with different elicitors alone or in combination at three physiologically active stages of fruit development $(5,15$, and 18 weeks after pollination) (Table 1). For the control treatments, date bunches received deionized water. 'Khenizi' bunches were harvested at Bisr stage (full-size and colored); the whole fruit should be red, and the red-green area should not exceed $10 \%$ on the bunch. The fruit were sorted to obtain the fully Bisr fruit. Then, fruit samples were collected (100 fruit of each treatment) for initial physical, physiochemical, phytochemical, and bioactive properties analysis at harvest time. For storage, a group of 500 uniform fruits from each replicate were randomly distributed among five perforated polyethylene bags $(30 \times 40 \mathrm{~cm})$ (100 fruit per bag), and stored in a cold room at $2{ }^{\circ} \mathrm{C}$ and $90 \%$ to $92 \%$ relative humidity (RH) (Ahmed et al., 2021a; Al-Qurashi and Awad, 2011) for 8 weeks. Every 2 weeks, one bag was randomly withdrawn for various analyses. For the biweekly weight loss and color measurements, another sample of 25 uniform fruits was separately packed and stored under the same conditions.

\section{Physiochemical analysis}

Fruit physical characteristics. At harvest, fruit weight and dimensions were recorded according to Rastegar et al. (2012). During storage, the fruit weight loss was recorded for each treatment once every 2 weeks and reported as a percentage of weight loss against the original weight before the cold storage, using the following equation:

Fruit weight $\operatorname{loss} \%=($ Initial weight

- Weight at specific interval)/

(Initial weight) $\times 100$

Fruit ripening and decay percentage. The fruit were visually observed for ripening (Rutab) evolution. Fruit that showed softening of $\approx 20 \%$ of its total area was considered Rutab. The decayed fruit were visually assessed by counting the fruit with any sign of microbial growth on the surface every other week up to full spoilage. The Rutab and decay percentages were calculated by using the following equations (Ahmed et al., 2021b; Kumar et al., 2013):

Rutab $(\%)=$ Number of Rutab fruit/

Total number of fruit $\times 100$

Decay $(\%)=$ Number of decay fruit/

Total number of fruit $\times 100$

Total soluble solids. Ten grams of mashed fruit was combined with $10 \mathrm{~mL}$ of distilled water. The blended juice was filtered and the clear juice was used. The total soluble solids (TSS) as a percentage value was determined in the juice using a digital refractometer (DR 6000; A. Kruss Optronic GmbH, Hamburg, Germany).

Fruit surface color. Surface color of fruit was assessed using a Hunter Laboratory colorimeter (Hunter Laboratory Inc., Reston, VA). The fruit's color values were expressed as $L^{*}$ (brightness), $b^{*}$ (red/green), and $a^{*}$ (blue/yellow) (CIELab, Kedron, Queensland, Australia). These values were then used to calculate the chroma $\left(C^{*}\right)$, total color difference $\left(\Delta E^{*}\right)$, and Hue angle $\left(H^{\circ}\right)$ as follows: $C^{*}=\left(a^{* 2}+b^{* 2}\right)^{1 / 2}, \Delta E=\left[\left(L^{*}-L^{*} 0\right)+\right.$ $\left.\left(a^{*}-a^{*} 0\right)+\left(b^{*}-b^{*} 0\right)\right]^{1 / 2}, H^{\circ}=180^{\circ}+$ $\arctan \left(b^{*} / a^{*}\right)$, where $L^{*} 0, a^{*} 0$, and $b^{*} 0$ values were from control fruit (Ahmed et al., 2021a; Maskan, 2001).

Determination of total microbial count. The microbiological assays were conducted in the microbiological food laboratory according

Table 1. Preharvest spry treatments of 'Khenizi' date fruit with different natural elicitors.

\begin{tabular}{|c|c|c|}
\hline Treatment & Chemical & Application \\
\hline Control & Water & Water \\
\hline $\mathrm{Ch}$ & Chitosan & $1 \%$ \\
\hline $\mathrm{Ca}$ & Calcium chloride & $3 \%$ \\
\hline SA & Salicylic acid & $2 \mathrm{mM}$ \\
\hline $\mathrm{Ch}+\mathrm{SA}$ & Chitosan + Salicylic acid & $1: 1, \mathrm{v} / \mathrm{V}$ \\
\hline $\mathrm{Ch}+\mathrm{Ca}$ & Chitosan + Calcium chloride & $1: 1, \mathrm{v} / \mathrm{v}$ \\
\hline $\mathrm{Ch}+\mathrm{Ca}+\mathrm{SA}$ & Chitosan + Calcium chloride + Salicylic acid & $1: 1: 1, \mathrm{v} / \mathrm{v} / \mathrm{v}$ \\
\hline
\end{tabular}

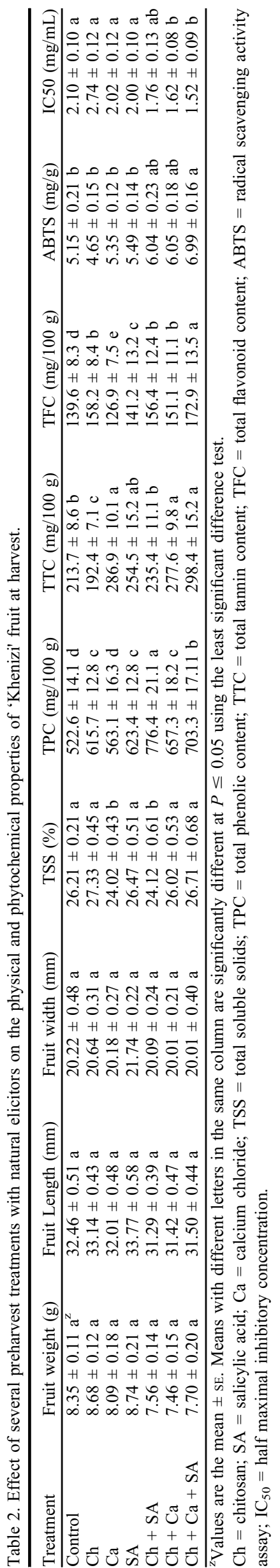

HortScience Vol. 57(3) March 2022 
Table 3. Effect of different preharvest treatments on total soluble solids content (TSS) of 'Khenizi' fruit during cold storage for $60 \mathrm{~d}$.

\begin{tabular}{|c|c|c|c|c|c|c|c|}
\hline Days after storage & Control & $\mathrm{Ch}$ & $\mathrm{Ca}$ & SA & $\mathrm{Ch}+\mathrm{SA}$ & $\mathrm{Ch}+\mathrm{Ca}$ & $\mathrm{Ch}+\mathrm{Ca}+\mathrm{SA}$ \\
\hline$\overline{15}$ & $33 \pm 1.65 \mathrm{Ca}^{\mathrm{z}}$ & $32 \pm 1.21 \mathrm{Ba}$ & $26 \pm 0.64 \mathrm{Cd}$ & $30 \pm 1.56 \mathrm{Cc}$ & $34 \pm 0.99 \mathrm{Ba}$ & $32 \pm 0.55 \mathrm{Cb}$ & $32 \pm 1.23 \mathrm{Bb}$ \\
\hline 45 & $37 \pm 0.95 \mathrm{ABb}$ & $36 \pm 1.94 \mathrm{Ab}$ & $33 \pm 2.03 \mathrm{Ac}$ & $35 \pm 0.69 \mathrm{Abc}$ & $39 \pm 2.21 \mathrm{Aa}$ & $34 \pm 1.32 \mathrm{Bc}$ & $33 \pm 0.94 \mathrm{Bc}$ \\
\hline
\end{tabular}

${ }^{\mathrm{z}}$ Values are the mean \pm sE. Means with different letters in the same row/column are significantly different at $P \leq 0.05$ using the least significant difference test.

Means with different letter(s) between treatments within a storage time point (small letter/row), and at different storage times (capital letter/column) are significantly different.

$\mathrm{Ch}=$ chitosan; $\mathrm{SA}=$ salicylic acid; $\mathrm{Ca}=$ calcium chloride .

to a method modified by Ahmed et al. (2021b). Total bacterial counts (TBCs) as well as yeast and mold counts (FMCs) were determined for treated and control date samples at harvest time (week 1) and at the end of the storage period (week 8). Under sterile conditions, $1 \mathrm{~g}$ of fruit tissue was aseptically mixed with $9 \mathrm{~mL}$ of sterile peptone water and used to prepare serial dilutions of samples. The pour plate technique was used to assess the fruit microbial load. Plate count agar was incubated at $37^{\circ} \mathrm{C}$ for $48 \mathrm{~h}$ and potato dextrose agar plate was incubated at $27^{\circ} \mathrm{C}$ for $5 \mathrm{~d}$. At the end of incubation time, the number of colonies was reported as $\log _{10}$ colony-forming units per gram of fresh weight $\left(\log _{10} \mathrm{CFU} \cdot \mathrm{g}^{-1}\right)$.

Extraction of bioactive compounds. The extraction of phenolic compounds from date fruit tissue was performed via homogenizing $2 \mathrm{~g}$ of fresh fruit samples in $20 \mathrm{~mL}$ of $80 \%$ methanol with water bath shaker at $150 \mathrm{rpm}$ for $24 \mathrm{~h}, 45^{\circ} \mathrm{C}$ (Ahmed et al., 2021a). Then the samples were filtered using Whatman \#1 filter paper. The supernatant (date extract) was used for further analysis.

\section{Phytochemical analysis}

Total phenolic content. Date extract (100 $\mu \mathrm{L}$ each) was added into tubes, followed by $50 \mu \mathrm{L}$ of Folin Ciocalteu reagent and vortexed. All the tubes were incubated at room temperature for $2 \mathrm{~min} ; 2 \mathrm{~mL} \mathrm{NaOH}(6 \%)$ was added to each tube. Absorbance was measured at $750 \mathrm{~nm}$ using a spectrophotometer. The TPC of samples was determined and expressed as milligram gallic acid equivalents (GAE) per $100 \mathrm{~g}$ of fresh weight (mg.100 $\mathrm{g}^{-1}$ GAE) using the standard curve obtained by measuring the absorbance of known concentrations of gallic acid (Velioglu et al., 1998).

Total tannin content. The amount of tannin in the date palm fruit extracts was determined using the colorimetric method described by Bentebba et al. (2020) with slight modification by Ahmed et al. (2021b), with some modifications; $1 \mathrm{~mL}$ of $4 \%$ ethanol vanillin solution and $0.2 \mathrm{~mL}$ of $\mathrm{HCl}(37 \%)$ were added to 0.4 $\mathrm{mL}$ of extract or catechin as standard. The mixture was shaken and reacted in the dark at room temperature for $15 \mathrm{~min}$ before measuring the absorbance of the pink color at $500 \mathrm{~nm}$ using a spectrophotometer. The results of total tannin were expressed as milligram of catechin equivalents per $100 \mathrm{~g}$ of fresh weight (mg. $100 \mathrm{~g}^{-1} \mathrm{CE}$ ).

Total flavonoid content. Total flavonoids were determined according to Kim et al.
(2003) with some modifications; $75 \mu \mathrm{L}$ of $\mathrm{NaNO}_{2}(5 \%)$ was added to the date extract $(250 \mu \mathrm{L})$ in a test tube and incubated for 5 min in the dark. Afterward, $75 \mu \mathrm{L}$ of $\mathrm{AlCl}_{3}$ $(10 \%)$ was added; the mixture was vortexed and kept in the dark for 6 min. After 6 min, $500 \mu \mathrm{L}$ of $\mathrm{NaOH}(1 \mathrm{M})$ was added, vortex mixed, and the volume was completed to 2.5 $\mathrm{mL}$ with distilled water. The absorbance was measured at $510 \mathrm{~nm}$ in a spectrophotometer (Shimadzu, Kyoto, Japan). The results were expressed as milligrams catechin per $100 \mathrm{~g}$ fresh weight basis (mg. $\left.100 \mathrm{~g}^{-1} \mathrm{CE}\right)$.

\section{Antioxidant activities}

Antioxidant activity was assessed by the ABTS [2,2'-Azino-bis (3-ethylbenzothiazoline-6-sulfonic acid) diammonium salt] and the DPPH (2,2-diphenyl-1-picrylhydrazyl) radical scavenging activity assays. ABTS scavenging activity was determined as described by Arnao et al. (2001). The stock solutions were ABTS solution $(7.4 \mathrm{~mm})$ and potassium persulfate solution $(2.6 \mathrm{~mm})$. The working solution was made by combining equal parts of the two stock solutions and allowing them to react for $12 \mathrm{~h}$ at ambient temperature in the dark. The solution was further diluted by combining $1 \mathrm{~mL}$ of ABTS solution with $50 \mathrm{~mL}$ of methanol, yielding an absorbance of $1.1 \pm 0.02$ units at $734 \mathrm{~nm}$ as measured with a spectrophotometer. For each assay, a fresh ABTS solution was made. Samples $(150 \mu \mathrm{L})$ with concentrations ranging from 0.5 to $10 \mathrm{mg} \cdot \mathrm{mL}^{-1}$ were combined with $2850 \mu \mathrm{L}$ of ABTS solution and left at room temperature for $2 \mathrm{~h}$ in the dark. The absorbance was then measured at $734 \mathrm{~nm}$. A sample blank for each concentration was made in the same way, except that methanol was used in place of ABTS solution. A Trolox standard curve ranging from 50 to 600 $\mu \mathrm{M}$ was generated. The activity was recorded as milligram of Trolox equivalents (TE) per $100 \mathrm{~g}$ fresh weight basis $\left(\mathrm{mg} \cdot \mathrm{g}^{-1} \mathrm{TE}\right)$.

The DPPH radical scavenging activity was measured according to $\mathrm{Wu}$ et al. (2003), with slight modifications. The $1.5-\mathrm{mL}$ samples with concentrations ranging from 0.5 to $10 \mathrm{mg} \cdot \mathrm{L}^{-1}$ were mixed with $1.5 \mathrm{~mL}$ of 0.15 $\mathrm{mm}$ DPPH in $95 \%$ ethanol. The mixture was allowed to stand at room temperature, in the dark, for $30 \mathrm{~min}$. The absorbance of the mixture was measured at $517 \mathrm{~nm}$, using a spectrophotometer. The blank for each concentration was made in the same way, except that ethanol was used in place of DPPH solution. Half maximal inhibitory concentration $\left(\mathrm{IC}_{50}\right)$ values $\left(\mathrm{mg} \cdot \mathrm{mL}^{-1}\right)$ were calculated for each sample.

\section{Statistical analysis}

The data from the completely randomized design with six replicates were subjected to statistical analysis using analysis of variance in the SAS statistical software (SAS Institute Inc., Cary, NC). Least significant differences at level $P \leq 0.05$ were used to compare means. Correlation coefficient between the main biochemical and physical characteristics was also done by SAS.

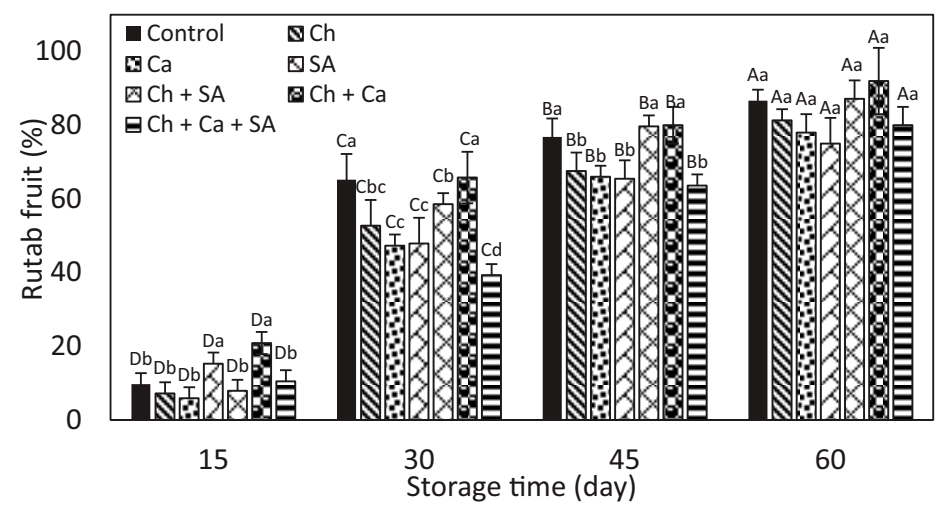

Fig. 1. Effect of different preharvest treatments on total phenol content of 'Khenizi' date palm fruit during cold storage for $60 \mathrm{~d}$, values are the mean \pm SE. Comparison between treatments means was made using the least significant difference test at $P \leq 0.05$. Means with different letter(s) between treatments within a storage time point (small letter), and at different storage times (capital letter) are significantly different. $\mathrm{Ch}=$ chitosan; $\mathrm{SA}=$ salicylic acid; $\mathrm{Ca}=$ calcium chloride . 


\section{Results and Discussion}

\section{Physical quality characteristics of fruits at harvest}

The average weight, width, and length of 'Khenizi' date palm fruits at harvest time are shown in Table 2. The average weight, length, and width of the $\mathrm{Ch}+\mathrm{SA}-, \mathrm{Ch}+\mathrm{Ca}-$, and $\mathrm{Ch}+\mathrm{SA}+\mathrm{Ca}$-treated fruits were lower $(P \leq$ $0.05)$ compared with other treatments, including the control; however, the differences were not statistically significant $(P \geq 0.05)$. The $\mathrm{Ch}+\mathrm{Ca}$ treatment had the lowest values, whereas SA followed by $\mathrm{Ch}$ treatments showed the highest values (Table 2). The improvements in physical properties of SAand Ch-treated fruits may be attributed to the role of SA and $\mathrm{Ch}$ in retaining cell integrity and improving carbohydrate sink, resulting in the fruit's size and weight increase (Kassem et al., 2010). On the other hand, the reduced physical measurements observed in the combined treatments $(\mathrm{Ch}+\mathrm{SA}, \mathrm{Ch}+\mathrm{Ca}$, and $\mathrm{Ch}+\mathrm{SA}+\mathrm{Ca}$ ) compared with other treatments could be due to the possible effect of the combined elicitors on cell membrane permeability, which affected water evaporation from fruit and hence fruit physical measurements. Physical qualities of a fruit were significant because they reflect the physical effect of the applied elicitors. Thus, more investigation is necessary to investigate the mechanism by which preharvest application of $\mathrm{Ch}$ in combination with $\mathrm{SA}$ and $\mathrm{Ca}$ affects the physical characteristics of fresh 'Khenizi' date palm fruit.

Total soluble solids. The TSS concentrations in 'Khenizi' date palm fruit at harvest time (Table 2) and during cold storage at $2{ }^{\circ} \mathrm{C}$ for $60 \mathrm{~d}$ are presented in Table 3. At harvest and during cold storage time, the TSS concentrations exhibited significant variations $(P \leq$ 0.05 ) between different treatments (Table 2). At harvest time, $\mathrm{Ca}$ followed by $\mathrm{Ch}+\mathrm{SA}$ treated fruits had significantly $(P \leq 0.05)$ lower TSS concentrations compared with other treatments, including the control. The TSS concentration gradually increased with the progress of ripening during cold storage (Table 3 ). After $45 \mathrm{~d}$ of cold storage, $\mathrm{Ch}+\mathrm{SA}+\mathrm{Ca}-$ and Ca-treated fruits had the lowest TSS concentrations, with $33 \%$ each, in relation to the control (37\%) and other treatments. At 15, 45, and 60 $\mathrm{d}$ of cold storage, $\mathrm{Ch}+\mathrm{SA}$-treated fruits had the highest TSS concentration, in comparison with all treatments, including the control (Table 3). Ca followed by $\mathrm{Ch}+\mathrm{SA}+\mathrm{Ca}$-treated fruits showed the lowest TSS concentrations. The lower TSS\% observed in $\mathrm{Ca}$ - and $\mathrm{Ch}+$
$\mathrm{SA}+\mathrm{Ca}$-treated fruits could be attributed to the effect of $\mathrm{Ca}$, either alone or in conjunction with $\mathrm{Ch}$ and SA on the breakdown of large polysaccharide molecules in treated fruits.

The TSS concentrations observed in this study were close to those recorded by Kassem et al. (2010) in 'Barhi' date cultivar at harvest. Correspondingly, they found lower TSS levels in SA-treated fruits compared with control fruit. Although, according to Mohamed et al. (2014), there was no significant difference between SA-treated and control 'Barhi' fruit. The increase in TSS during cold storage could be attributed to the degradation of large polysaccharide molecules into smaller sugars through enzymatic activities, as well as the loss of water during storage (Hazbavi et al., 2015; Mohamed et al., 2014). Based on our findings, it may suggest that the use of $\mathrm{Ca}$ alone or in combination with $\mathrm{Ch}$ and SA reduced TSS concentrations in treated date fruits, most likely by decelerating the degradation reactions of large polysaccharide molecules.

\section{Total phenolic, tannin, and flavonoid content of treated and control fruit}

Table 2 presents the results of TPC, total flavonoid content (TFC), and total tannin content (TTC) at harvest time. At harvest, the TPC, TFC, and TTC contents differed significantly $(P \leq 0.05)$ across treatments, as influenced by the applied elicitors. The highest TPC content was observed in fruit treated with $\mathrm{Ch}+\mathrm{SA}$, with $776.4 \mathrm{mg} \cdot 100 \mathrm{~g}^{-1}$ followed by $\mathrm{Ch}+\mathrm{SA}+$ $\mathrm{Ca}$, with $703.3 \mathrm{mg} \cdot 100 \mathrm{~g}^{-1}$ (Table 2). Among all treatments, $\mathrm{CH}+\mathrm{SA}+\mathrm{Ca}$-treated fruits had the highest TTC and TFC contents, with 298.4 and $172.9 \mathrm{mg} \cdot 100 \mathrm{~g}^{-1}$, respectively (Table 2). This observation could be because of the potential effect of the combined elicitors used, which involves stimulating the synthesis of phytochemical compounds (Baenas et al., 2014; Romanazzi et al., 2018). Similar observation had been reported by Rahman et al. (2018), who found that Chpreharvest spray significantly increased phenolic and flavonoid compounds up to 2.6-fold in treated strawberry fruit compared with the control.

TPC content of 'Khenizi' fruits varied significantly $(P \leq 0.05)$ between different treatments during the cold storage period (Fig. 1). Also, TPC levels in 'Khenizi' date fruit declined as the fruit ripened during storage. After $15 \mathrm{~d}$ of storage, $\mathrm{CH}$ followed by $\mathrm{Ch}+\mathrm{SA}$ and $\mathrm{Ch}+\mathrm{SA}+\mathrm{Ca}$ treatments had the highest TPC content, with 290, 230, and 201 $\mathrm{mg} \cdot 100 \mathrm{~g}^{-1}$, respectively (Fig. 1), although after $30 \mathrm{~d}, \mathrm{Ch}+\mathrm{SA}$-treated fruits had significantly higher TPC content compared with the other treatments, including the control. After 45 and $60 \mathrm{~d}$, slight variances were observed between different treatments. TPC content had been reported to vary considerably across date cultivars, with a range of 50 to 400 $\mathrm{mg} \cdot 100 \mathrm{~g}^{-1}$ fresh weight (Al-Qurashi and Awad, 2011; Awad et al., 2011; Mohamed et al., 2014). Based on these results, the used elicitors' combinations showed a synergistic effect to increase the levels of TPC, TFC, and TTC in 'Khenizi' date palm fruit, thus improving fruit quality.

\section{Antioxidant activity at harvest}

The effect of different elicitation treatments on the antioxidant activity was assessed at harvest time (Table 2). The antioxidant activity varied significantly $(P \leq 0.05)$ among different treatments as affected by the applied elicitors. The ABTS radical scavenging activities test results showed that $\mathrm{Ch}+\mathrm{SA}+\mathrm{Ca}-$ treated date palm fruit had the highest antioxidant activity, with $6.9 \mathrm{mg} \cdot \mathrm{g}^{-1}$ followed by $\mathrm{Ch}+\mathrm{Ca}$ - and $\mathrm{Ch}+\mathrm{SA}$-treated fruits, with 6.04 $\mathrm{mg} \cdot \mathrm{g}^{-1}$ each. These results are consistent with the DPPH radical scavenging activities test, with $\mathrm{IC}_{50}$ values of $1.5,1.6$, and $1.7 \mathrm{mg} \cdot \mathrm{mL}^{-1}$ for $\mathrm{Ch}+\mathrm{SA}+\mathrm{Ca}-, \mathrm{Ch}+\mathrm{Ca}-$, and $\mathrm{Ch}+\mathrm{SA}-$ treated fruits, respectively (Table 2). The lower $\mathrm{IC}_{50}$ values in the $\mathrm{DPPH}$ determination revealed a reduction in the extract concentration needed to scavenge the DPPH radical by $50 \%$, indicating an improvement in antioxidant activity. These results might be because of the elicitors' synergistic effect, most likely by boosting antioxidant activities in treated fruits (Baenas et al., 2014; Romanazzi et al., 2018; Wang et al., 2006). The results of antioxidant activities are in line with those observed for TPC at harvest (Table 2), suggesting a critical role of phenolic compounds in the antioxidant capacity of 'Khenizi' fruit. Awad et al. (2011) reported positive correlation between the antioxidant capacity and the antioxidant compound content in some date palm cultivars, including Khenizi. Overall, the antioxidant concentration in dates decreases as they develop from the mature stage (Bisr) to the ripe stages (Rutab and Tamer) (Awad et al., 2011). The reduction in antioxidant compounds in date fruit during maturity and ripening (Bisr and Rutab stages) was considered to be because of the oxidative stress (Mohamed et al., 2014). As a result, more reactive oxygen species are likely to develop and become involved in the ripening/senescence process of date fruit

Table 4. Effect of preharvest treatments with natural elicitors on weight loss of 'Khenizi' fruit during cold storage for $60 \mathrm{~d}$.

\begin{tabular}{|c|c|c|c|c|c|c|c|}
\hline $\begin{array}{l}\text { Days after } \\
\text { storage }\end{array}$ & Control & $\mathrm{Ch}$ & $\mathrm{Ca}$ & SA & $\mathrm{Ch}+\mathrm{SA}$ & $\mathrm{Ch}+\mathrm{Ca}$ & $\mathrm{Ch}+\mathrm{Ca}+\mathrm{SA}$ \\
\hline 30 & $10.38 \pm 0.47 \mathrm{Ca}$ & $7.72 \pm 0.42 \mathrm{Cb}$ & $10.52 \pm 0.61 \mathrm{Ca}$ & $10.1 \pm 0.55 \mathrm{Ca}$ & $7.23 \pm 0.16 \mathrm{Cb}$ & $6.81 \pm 0.32 \mathrm{Cb}$ & $7.72 \pm 0.45 \mathrm{Cb}$ \\
\hline 60 & $20.98 \pm 1.06 \mathrm{Aa}$ & $17.06 \pm 1.23 \mathrm{Ab}$ & $19.54 \pm 1.16 \mathrm{Aa}$ & $19.56 \pm 0.93 \mathrm{Aa}$ & $19.58 \pm 0.88 \mathrm{Aa}$ & $17.74 \pm 0.86 \mathrm{Ab}$ & $18.19 \pm 1.51 \mathrm{Ab}$ \\
\hline
\end{tabular}

${ }^{\mathrm{z}}$ Values are the mean \pm SE. Means with different letters in the same row/column are significantly different at $P \leq 0.05$ using the least significant difference test. Means with different letter(s) between treatments within a storage time point (small letter/row), and at different storage times (capital letter/column) are significantly different.

$\mathrm{Ch}=$ chitosan; $\mathrm{SA}=$ salicylic acid $\mathrm{Ca}=$ calcium chloride 


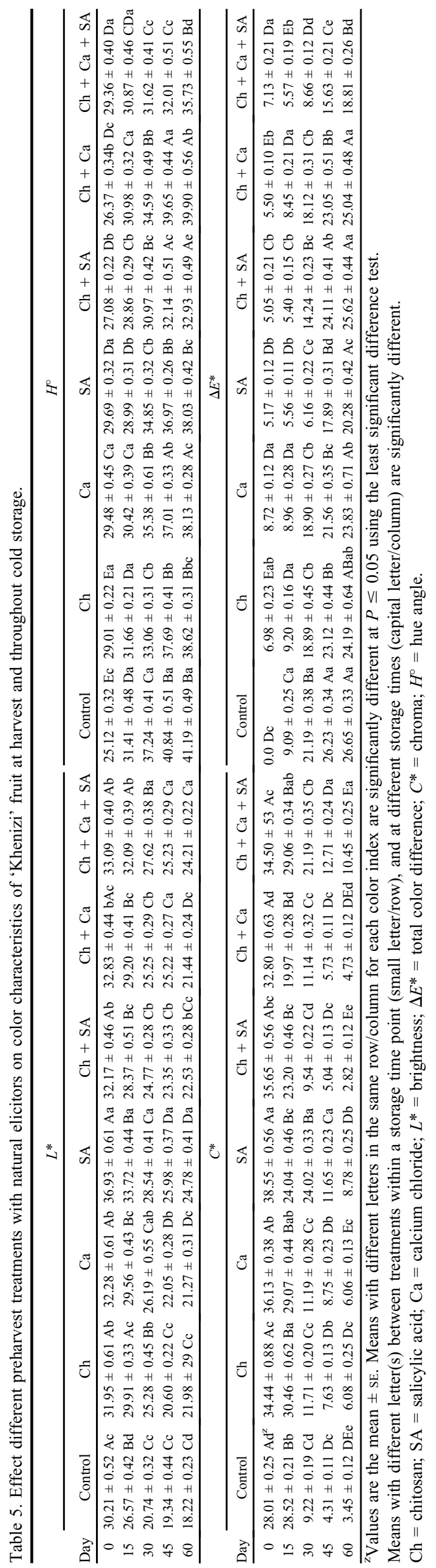

(Ferrer et al., 2005). The result of preharvest treatments of $\mathrm{Ch}, \mathrm{Ca}$, and $\mathrm{SA}$ in combination increased antioxidant activity, which enhanced the quality of 'Khenizi' date palm fruit, most likely by decreasing harmful radicals.

\section{Fruit weight loss during cold storage period}

Results in Table 4 show the weight loss percentages in 'Khenizi' date palm fruit during $45 \mathrm{~d}$ of cold storage at $2{ }^{\circ} \mathrm{C}$ and $\mathrm{RH} 90 \%$ to $92 \%$. Weight loss occurred gradually at different levels in different treatment groups during the storage period. Fruit weight loss varied significantly $(P \leq 0.05)$ among treatments during the cold storage period. After $30 \mathrm{~d}$ of cold storage, $\mathrm{Ch}+\mathrm{Ca}$ treatment followed by $\mathrm{Ch}+\mathrm{SA}-, \mathrm{Ch}+\mathrm{SA}+\mathrm{Ca}-$, and $\mathrm{Ch}-$ treated fruits had significantly $(P \leq 0.05)$ lower weight loss than other treatments. By the end of the storage period, the lowest weight loss was observed in Ch- followed by $\mathrm{Ch}+\mathrm{SA}-$ and $\mathrm{Ch}+\mathrm{SA}+\mathrm{Ca}$-treated fruits, with $17.0 \%, 17.7 \%$, and $18.1 \%$, respectively, whereas the control treatment had the highest value $(20.9 \%)$ (Table 4$)$. In general, weight loss during the storage period can be attributed to the increase in respiration rate and/or moisture loss from the fruits (Atia et al., 2018; Mohamed et al., 2014; Shiri et al., 2013). The lowest weight loss noticed in fruits treated with $\mathrm{Ch}$ alone or in combination with other elicitors could be attributed to the film-forming properties of $\mathrm{Ch}$, which greatly reduced the evaporation rate of water from the fruit, as reported with other Ch-treated fruits (Petriccione et al., 2015a, 2015b; Romanazzi et al., 2018). Moreover, it had been reported that prestorage treatment with $\mathrm{Ca}$ decreased weight loss better than SA in 'Barhi' dates at the Bisr stage (Atia et al., 2020). In addition, preharvest use of SA decreased weight loss during storage in treated 'Barhi' date palm fruit relative to the control (Ahmed et al., 2021a; Kassem et al., 2010; Mohamed et al., 2014). SA treatment is well known for its ability to mitigate chilling damage, delay ripening, and react against a variety of abiotic and biotic causes (Ennab et al., 2020).

Weight loss is a major factor that limits the storability and marketability of postharvest fruit (Kassem et al., 2010; Mohamed et al., 2014). In date palm, the weight of the fruit generally increases as maturation advances and reaches its peak at the Bisr stage, then rapidly declines as ripening proceeds (Alqarni and Bazzi, 2019). Our results show that the weight loss reduction observed in fruits of Ch treatment alone or in combination with SA and $\mathrm{Ca}$ treatments, indicates the good physiological conditions of the treated fruits, most likely as a result of the potential regulating effect of the applied elicitors on the ripening process.

\section{Color attributes}

Color is an important visual aspect of food, particularly in fresh fruits and vegetables, and it can affect product attractiveness and acceptability by the consumers (Fernández-Vázquez et al., 2011). For evaluating fruit color quality, 


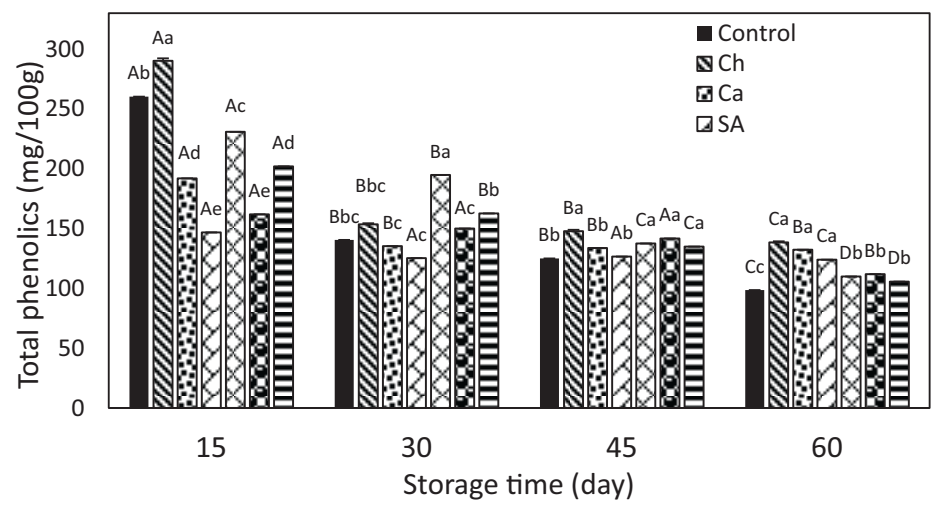

Fig. 2. Effect of different preharvest treatments on 'Khenizi' date pam fruit ripening (\% Rutab) during cold storage for $60 \mathrm{~d}$, values are the mean \pm SE. Comparison between treatments means was made using the least significant difference test at $P \leq 0.05$. Means with different letter(s) between treatments within a storage time point (small letter), and at different storage times (capital letter) are significantly different. $\mathrm{Ch}=$ chitosan; $\mathrm{SA}=$ salicylic acid; $\mathrm{Ca}=$ calcium chloride.

the effect of treatments on color characteristics was assessed at harvest time and during the storage period. Important color parameters (i.e., $L^{*}, H^{\circ}, C^{*}$, and $\Delta E$ ) are presented in Table 5. In general, color parameters were significantly $(P \leq 0.05)$ affected by the use of elicitors. In all fruits, color parameters progressively decreased with the progress of storage time, except for SA- and $\mathrm{Ch}+\mathrm{SA}+\mathrm{Ca}$-treated fruits, which showed the smallest alteration in color quality. The $L^{*}$ value decreased significantly $(P \leq 0.05)$ with storage progress in all date palm fruits, indicating a loss in fruit lightness and a change in color from red to brownish. At the end of the storage time, the lowest decrease in $L^{*}$ value was noticed in SA- and $\mathrm{Ch}+\mathrm{Ca}+\mathrm{SA}$-treated fruits in comparison with other treatments, including the control treatment (Table 5). In addition, $C^{*}$ and $H^{\circ}$ levels were also the highest in these treatments. The same treatments also had lower $\Delta E$ values than other treatments, including the control treatment. Moreover, $L^{*}, C^{*}$, and $H^{\circ}$ values were positively correlated (Table 7 ) with the increased TSS depicted in Table 3, whereas $\Delta E$ was opposite. The observed delay in color change in the SA and $\mathrm{Ch}+\mathrm{Ca}+\mathrm{SA}$-treated fruits could be because of the potential effect of SA alone or in conjunction with $\mathrm{Ch}$ and $\mathrm{Ca}$ on the enzymatic color reactions, decreasing change in the fruit color properties. Similar observation was reported by Molamohammadi et al. (2020), who found that SA-treated pistachio fruit had better color characteristics than the control (Molamohammadi et al., 2020).

Deteriorative color reactions (fruit browning in date), especially enzymatic ones, are a natural phenomenon caused primarily by the activity of peroxidase and polyphenol oxidase during the ripening process and storage, and are associated with fruit market value loss (Awad et al., 2011; Mortazavi et al., 2015; Panahirad et al., 2019). Based on the current findings, application of SA treatment alone or in combination with $\mathrm{Ch}$ and $\mathrm{Ca}$ treatments could preserve 'Khenizi' date fruit color quality, most likely by delaying harmful color reactions.

\section{Fruit ripening}

The results for fruit ripening during cold storage at $2{ }^{\circ} \mathrm{C}$ for $60 \mathrm{~d}$ are presented as Rutab percentage in Fig. 2. The results revealed that different treatments significantly $(P \leq 0.05)$ slowed fruit ripening during storage as compared with the control. In general, Rutab percentage gradually increased during cold storage in all treatments at varying degrees. After $30 \mathrm{~d}$ of storage, $\mathrm{Ch}+\mathrm{SA}+\mathrm{Ca}-$ treated fruit showed significantly $(P \leq 0.05)$ lower Rutab percentages $(39 \%)$ in comparison with the other treatments, including the control. At day $45, \mathrm{Ch}+\mathrm{SA}+\mathrm{Ca}-$ followed by SA-, Ca-, and Ch-treated fruits had significantly $(P \leq 0.05)$ lower Rutab percentages, with $63 \%, 65 \%, 66 \%$, and $67 \%$, respectively, than other treatments, including the control treatment (Fig. 2). By the end of the storage period, differences observed among treatments were not statistically significant. These results are consistent with TSS results shown in Table 3 and were supported by the significant positive correlation shown in Table 4 . $\mathrm{Ch}+\mathrm{SA}+\mathrm{Ca}$-treated fruits had the lowest TSS content after $45 \mathrm{~d}$ of storage. These finding could also be interpreted as an evidence of the synergistic effect of elicitors on delaying the ripening of 'Khenizi' fruit during cold storage. Preharvest use of SA postponed the ripening of 'Barhi' date by 3 weeks as compared with the control fruit (Kassem et al., 2010). Also, it may suggest that the filmforming ability of $\mathrm{Ch}$ combined with other elicitors can delay fruit ripening by providing a barrier for gas exchanges and decreased respiration. It is worth noting that less ripe fruit

Table 6. Effect of different preharvest treatments on 'Khenizi' fruit decay during cold storage for $60 \mathrm{~d}$.

\begin{tabular}{lccccccc}
\hline Days after storage & Control & Ch & Ca & SA & Ch + SA & Ch + Ca & Ch + Ca + SA \\
\hline 15 & ND & ND & ND & ND & ND & ND & ND \\
30 & $5.10 \pm 0.05 \mathrm{c}^{z}$ & ND & ND & ND & ND & ND & ND \\
45 & $23.68 \pm 0.43 \mathrm{~b}$ & ND & ND & ND & ND & ND \\
60 & $34.20 \pm 0.92 \mathrm{a}$ & $10.01 \pm 0.83 \mathrm{~b}$ & $4.04 \pm 0.22 \mathrm{c}$ & $5.21 \pm 0.23 \mathrm{c}$ & $5.61 \pm 0.21 \mathrm{c}$ & $5.11 \pm 0.22 \mathrm{c}$ & $5.31 \pm 0.25 \mathrm{c}$ \\
\hline
\end{tabular}

${ }^{\mathrm{z}}$ Values are the mean \pm SE. Means with different letters in the same row/column are significantly different at $P \leq 0.05$ using the least significant difference test.

$\mathrm{Ch}=$ chitosan $\mathrm{SA}=$ salicylic acid $\mathrm{Ca}=$ calcium chloride $\mathrm{ND}=$ not detected .

Table 7. Pearson's correlation coefficients between main biochemical and physical characteristics of 'Khenizi' fruit.

\begin{tabular}{|c|c|c|c|c|c|c|c|c|}
\hline Traits & TSS & TPC & Rutab (\%) & Decay (\%) & Weight loss (\%) & $L^{*}$ & $\Delta E^{*}$ & $C^{*}$ \\
\hline$\overline{\mathrm{TPC}}$ & $-0.75 * * * y$ & & & & & & & \\
\hline Decay $(\%)$ & $0.62 * * *$ & $-0.47 * * *$ & $0.59 * * *$ & & & & & \\
\hline$L^{*}$ & $-0.69 * * *$ & $0.87 * * *$ & $-0.90 * * *$ & $-0.40 * * *$ & $-0.62 * * *$ & & & \\
\hline$\Delta E$ & $0.66 * * *$ & $-0.81 * * *$ & $0.88 * * *$ & $0.45^{* * *}$ & $0.56^{* * * *}$ & $-0.96 * * *$ & & \\
\hline$C^{*}$ & $-0.63 * * *$ & $0.71 * * *$ & $-0.82^{* * *}$ & $-0.49 * * *$ & $-0.52 * * *$ & $0.93^{* * *}$ & $-0.95^{* * *}$ & \\
\hline$H^{\circ}$ & $-0.69 * * *$ & $0.81 * * *$ & $-0.89 * * *$ & $-0.55 * * *$ & $-0.63 * * *$ & $0.92 * * *$ & $-0.91 * * *$ & $0.91 * * *$ \\
\hline
\end{tabular}

TSS $=$ total soluble solids; TPC $=$ total phenolic content; $L^{*}=$ brightness; $\Delta E^{*}=$ total color difference; $C^{*}=$ chroma; $H^{\circ}=$ hue angle.

*** Significant at level $P=0.001$. 

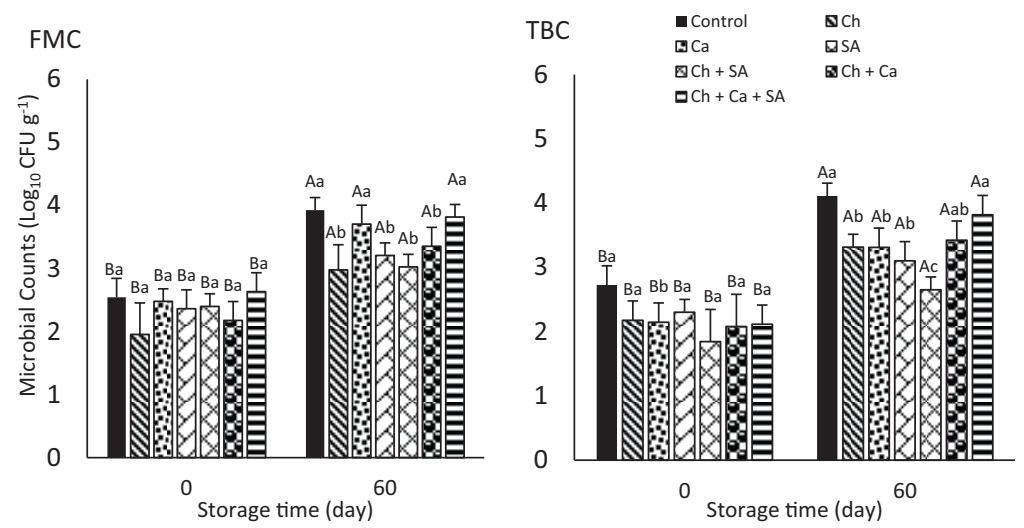

Fig. 3. The effect of preharvest treatment on microbial $\operatorname{load}\left(\log 10 \mathrm{CFU} \cdot \mathrm{g}^{-1}\right)$ of 'Khinizi' date palm fruit during cold storage (day 0 and day 60 ). Values are the mean \pm SE. Comparison between treatment means was made using the least significant difference test at $P \leq 0.05$. Means with different letter(s) between treatments within a storage time point (small letter), and at different storage times (capital letter) are significantly different. $\mathrm{Ch}=$ chitosan; $\mathrm{SA}=$ salicylic acid; $\mathrm{Ca}=$ calcium chloride; $\mathrm{FMC}=$ fungal $/$ mold count; $\mathrm{TBC}=$ total bacterial count.

is less susceptible to postharvest rot (Romanazzi et al., 2018).

Fruit ripening is a natural phenomenon that causes membrane impermeability and, ultimately, senescence owing to oxidation of cell membrane vital components (Awad et al., 2011). The mechanism by which elicitors exert their effects involves decreasing ethylene production in vegetables and fruits (Baenas et al., 2014; Romanazzi et al., 2018). Ethylene is believed to have a significant role in the ripening and senescence processes; accordingly, it is possible that sprayed elicitors might control the ethylene production or action, and thus decreased fruit ripening (reduction in Rutab occurrence). Our results showed a synergistic effect of $\mathrm{Ch}, \mathrm{Ca}$, and $\mathrm{SA}$ treatment in combination on delaying the fruit ripening/senescence compared with other treatments, including the control. However, date maturation is not an asynchronous phenomenon in which all date fruits in the same bunch mature around the same period, as there can be fruits in different stages of maturation in the same bunch at any given time. In the same bunch, fruits that had the same application, for instance, could reach the Rutab stage at different times. As a result, there are significant biological differences between individual fruits (Mohamed et al., 2014). Thus, large natural biological differences among individual fruits within the same bunch need to be considered for some varying results.

\section{Decay incidence during storage period}

Table 6 presents the percentages of fruit decay during cold storage at $2{ }^{\circ} \mathrm{C}$ and $90 \%$ to $92 \% \mathrm{RH}$ for $60 \mathrm{~d}$. All preharvest spray-treated fruits had significantly $(P \leq 0.05)$ lower fruit decay incidence than the control fruit throughout the cold storage period. In the control fruit, the decay started after $30 \mathrm{~d}$ of cold storage and gradually increased to reach $\approx 23 \%$, whereas no decay was observed in treated fruits (Table 6). At day 60 of cold storage, the highest decay percentage was observed with control fruit (with $\approx 34 \%$ ), followed by Ch-treated fruit (with $\approx 10 \%$ decay). In treated fruits, the decay ranged from $\approx 5 \%$ to $10 \%$, with no significant variations $(P \geq 0.05)$ among treatments (Table 6). SA has previously been shown to reduce peach chilling damage during cold storage due to its ability to boost antioxidant activities (Wang et al., 2006). Also, SA at concentrations of 1 and $2 \mathrm{mmol} \cdot \mathrm{L}^{-1}$ has been shown to be effective in minimizing decay incidence in grapes (Gomes et al., 2021).

Treatments of SA and Ca, separately or in combination, improved strawberry fruit rigidity and delayed softening, resulting in less rotten fruit (Shafiee et al., 2010). Furthermore, the use of $\mathrm{SA}, \mathrm{Ca}$, and oxalic acid treatments have been reported to stimulate a defensive response and reduce decay in different fruits (Shen and Yang, 2017; Tian et al., 2006; Wang et al., 2011). In this study, TPC was shown to have a negative correlation with weight loss, Rutab, and decay percentages (Table 7), indicating the role of phenolic compounds in date fruit ripening/ senescence. The preceding results showed that using $\mathrm{Ch}$ in conjunction with $\mathrm{Ca}$ and $\mathrm{SA}$ treatments could protect 'Khenizi' date palm fruit from rotting for an extended period during cold storage, most likely by activating defense mechanisms in the date palm fruit.

\section{Microbiological quality of fruits}

The microbial counts $\left(\log _{10} \mathrm{CFU} \cdot \mathrm{g}^{-1}\right)$ on 'Khenizi' date palm samples at harvest time and by end of the cold storage period are shown in Fig. 3. In general, yeast/mold counts (FMCs) and TBCs differed significantly $(P \leq 0.05)$ among treatments at harvest and at the end of the storage period, as impacted by elicitor application. At day 0 , all treated fruits had slightly lower TBCs compared with the control treatment; however, the differences were not statistically significant $(P \geq 0.05)$. The FMCs were significantly $(P \leq 0.05)$ lower in Ch-treated fruit than other treatments and the control treatment. By the end of the storage period (day 60), $\mathrm{Ch}+\mathrm{SA}$ had significantly lower TBCs than other treatments and the control. In addition,
$\mathrm{Ch}+\mathrm{SA}$ and SA treatments showed the lowest FMC load as compared with other treatments, including the control treatment (Fig. 3). Tian et al. (2006) reported that, among all elicitors, SA exhibited the greatest effect in stimulating defense reactions and reducing decay in pear fruit. Also, Ch showed ability to stimulate plant defense against a range of microbial fungal and bacterial pathogens (Romanazzi et al., 2018). Recent reports found that $\mathrm{Ch}$ and SA treatments, either alone or in combination, dramatically reduced bacterial and fungal development in fruit (Ahmed et al., 2021a; Molamohammadi et al., 2020). According to this study, using Ch and SA in combination reduced the microbial load on 'Khenizi' date palm fruit during the storage period, most likely through inducing defensive mechanisms that contribute to pathogen resistance and therefore improved 'Khenizi' date palm fruit quality.

\section{Conclusion}

The results of this study show that as compared with individual applications of $\mathrm{Ch}, \mathrm{SA}$, or $\mathrm{Ca}$, a combination of these elicitors had significantly better influence on fruit quality during storage. Accordingly, the valuable aspect of the present study is that it provides evidence that a combination of these elicitors has the potential to improve fruit quality at harvest time, as well as during the postharvest storage period. Future studies should focus on fine-tuning the concentrations and combinations that may have commercial applications on date fruit from other cultivars or fruit from other crops to improve the quality marketability.

\section{Literature Cited}

Abd Elwahab, S.A., A.M.A. Allatif, M.A. Farid, and S.M. Soliman. 2019. Effect of safe post-harvest alternatives on quality and storage life of 'Barhi' date palm. Plant Arch. 19(2):3937-3945.

Abu-Shama, H.S., F.O.F. Abou-Zaid, and E.Z. El-Sayed. 2020. Effect of using edible coatings on fruit quality of Barhi date cultivar. Scientia Hort. 265:109262, https://doi.org/10.1016/j.scienta. 2020.109262.

Ahmed, Z.F.R. and J.P. Palta. 2015. A natural lipid, Lysophosphatidylethanolamine, may promote ripening while reducing senescence in banana fruit. HortScience 50:1035-1040, https://doi.org/10.21273/HORTSCI.50.7.1035.

Ahmed, Z.F.R. and J.P. Palta. 2017. Hormone-like action of a natural lipid, lysophosphatidylethanolamine: A comparison with auxin. Acta Hort. 1187:107-114, https://doi.org/10.17660/ ActaHortic.2017.1187.13.

Ahmed, Z.F.R., F.Y.Y. Al Shaibani, N. Kaur, S. Maqsood, and G. Schmeda-Hirschmann. 2021a. Improving fruit quality, bioactive compounds, and storage life of date palm (Phoenix dactylifera L., cv. Barhi) using natural elicitors. Horticulturae 7:293, https://doi.org/10.3390/horticulturae7090 293.

Ahmed, Z.F.R., S.S.N.A. Alblooshi, N. Kaur, S. Maqsood, and G. Schmeda-Hirschmann. 2021b. Synergistic effect of preharvest spray application of natural elicitors on storage life and bioactive compounds of date palm (Phoenix dactylifera L., cv. Khesab). Horticulturae 7:145, https://doi.org/10.3390/horticulturae7060145. 
Al-Mssallem, M.Q., R.M. Alqurashi, and J.M. AlKhayri. 2020. Bioactive compounds of date palm (Phoenix dactylifera L.), p. 91-105. In: H.N. Murthy and V.A. Bapat (eds.). Bioactive compounds in underutilized fruit and nuts. Springer Int. Publishing, New York.

Al-Qurashi, A.D. and M.A. Awad. 2011. Quality characteristics of bisir 'Barhee' dates during cold storage as affected by postharvest dipping in gibberellic acid, naphthaleneacetic acid and benzyladenine. Fruits 66:343-352, https://doi. org/10.1051/fruit/2011048.

Al-Shwyeh, H.A. 2019. Date palm (Phoenix dactylifera $\mathrm{L}$.) fruit as potential antioxidant and antimicrobial agents. J. Pharm. Bioallied Sci. 11:1-11, https://doi.org/10.4103/jpbs.JPBS_168_18.

Aleid, S. and M.J.J.F.N.R. Saikhan. 2017. Effect of permeable modified atmosphere packaging on quality and shelf life of fresh Khenaizy dates stored at low temperature. Food Nutr. Res. 5:503-509, https://doi.org/10.12691/jfnr-5-7-8.

Alhamdan, A.M., D.O. Elkhair, and K.A. Ehmed. 2015. Modeling of respiration rate of fresh date fruits (Barhi cultivar) under aerobic conditions. J. Adv. Agr. Technol. 2:120-124, https://doi. org/10.12720/joaat.2.2.120-124.

Alqarni, S. and M.D. Bazzi. 2019. Evaluating the Phoenix dactylifera L. biochemical changes associated with its maturation. J. Agr. Sci. 11: 614-624, https://doi.org/10.5539/jas.v11n3p614.

Alsawmahi, O.N., F. Al-Juhaimi, A.M. Alhamdan, K. Ghafoor, O.Q. Adiamo, I.A. Mohamed Ahmed, B.H. Hassan, K.A. Ehmed, E.E. Babiker, D. Abdelkarim, M. Younis, and N. Alashmawe. 2018. Phenolic, tannin, antioxidant, color, and sensory attributes of Barhi date (Phoenix dactylifera) fruit stored in modified atmosphere packages. J. Food Biochem. 42:e12576, https://doi.org/10.1111/jfbc. 12576.

Arnao, M.B., A. Cano, and M. Acosta. 2001. The hydrophilic and lipophilic contribution to total antioxidant activity. Food Chem. 73:239-244, https://doi.org/10.1016/S0308-8146(00)00324-1.

Atia, A., D. Abdelkarim, M. Younis, and A. Alhamdan. 2018. Effects of calcium chloride and salicylic acid postharvest treatments on the quality of Khalal Barhi dates at different ripening levels during cold storage. J. Food Meas. Charact. 12:1156-1166, https://doi.org/10.1007/ s11694-018-9729-0.

Atia, A., D. Abdelkarim, M. Younis, A. Alhamdan, and B. Engineering. 2020. Effects of pre-storage dipping in calcium chloride and salicylic acid on the quality attributes of stored Khalal Barhi dates. Int. J. Agron. 13:206-212, https://doi.org/ 10.25165/j.ijabe.20201303.4983.

Awad, M.A., A.D. Al-Qurashi, and S.A. Mohamed. 2011. Antioxidant capacity, antioxidant compounds and antioxidant enzyme activities in five date cultivars during development and ripening. Scientia Hort. 129:688-693, https://doi. org/10.1016/j.scienta.2011.05.019.

Baenas, N., C. García-Viguera, and D.A. Moreno. 2014. Elicitation: A tool for enriching the bioactive composition of foods. Molecules 19: 13541-13563, https://doi.org/10.3390/molecules 190913541.

Bentebba, F.Z., G. Zineb, M. Saidi, and C. Bensaci. 2020. Effects of development and ripening stage on phytochemical compositions, antioxidant and antibacterial activities of date palm fruits. Asian J. Chem. 32:415-419, https://doi.org/10.14233/ ajchem.2020.22404.

Bentrad, N. and A. Hamida-Ferhat. 2020. Date palm fruit (Phoenix dactylifera): Nutritional values and potential benefits on health, p. 239-255. In: V.R. Preedy and R.R. Watson (eds.). The mediterranean diet. 2nd ed. Academic Press, Cambridge, MA.

Chen, Y., J. Sun, H. Lin, M. Lin, Y. Lin, H. Wang, and Y.C. Hung. 2020. Salicylic acid treatment suppresses Phomopsis longanae Chi-induced disease development of postharvest longan fruit by modulating membrane lipid metabolism. Postharvest Biol. Technol. 164:111168, https:// doi.org/10.1016/j.postharvbio.2020.111168.

Ennab, H.A., M.A. El-Shemy, and S.M. Alam-Eldein. 2020. Salicylic acid and putrescine to reduce post-harvest storage problems and maintain quality of murcott mandarin fruit. Agronomy (Basel) 10:115, https://doi.org/10.3390/ agronomy 10010115 .

Fernández-Vázquez, R., C.M. Stinco, A.J. MeléndezMartínez, F.J. Heredia, and I.M. Vicario. 2011. Visual and instrumental evaluation of orange juice color: A consumers'preference study. J. Sens. Stud. 26:436-444, https://doi.org/10.1111/j.1745459X.2011.00360.x.

Ferrer, A., S. Remón, A.I. Negueruela, and R. Oria. 2005. Changes during the ripening of the very late season Spanish peach cultivar Calanda: Feasibility of using CIELAB coordinates as maturity indices. Scientia Hort. 105:435-446, https://doi. org/10.1016/j.scienta.2005.02.002.

Gomes, E.P., C. Vanz Borges, G.C. Monteiro, M.A. Filiol Belin, I.O. Minatel, A. Pimentel, Jr., M.A. Tecchio, and G.P.P. Lima. 2021. Preharvest salicylic acid treatments improve phenolic compounds and biogenic amines in 'Niagara Rosada' table grape. Postharvest Biol. Technol. 176:111505, https://doi.org/10.1016/j. postharvbio.2021.111505.

Hazbavi, I., M.H. Khoshtaghaza, A. Mostaan, and A. Banakar. 2015. Effect of postharvest hot-water and heat treatment on quality of date palm (cv. Stamaran). J. Saudi Soc. Agr. Sci. 14:153-159, https://doi.org/10.1016/j.jssas.2013.10.003.

Irfan, P.K., V. Vanjakshi, M.N.K. Prakash, R. Ravi, and V.B. Kudachikar. 2013. Calcium chloride extends the keeping quality of fig fruit (Ficus carica L.) during storage and shelf-life. Postharvest Biol. Technol. 82:70-75, https:// doi.org/10.1016/j.postharvbio.2013.02.008.

Kassem, H., R. Alobeed, and M. Ahmed. 2010. Extending harvest season, improving fruit quality and shelf life of 'Barhee' date palm by preharvest sprays. Acta Hort. 882:147-154, https://doi.org/ 10.17660/ActaHortic.2010.882.16.

Kim, D.-O., O.K. Chun, Y.J. Kim, H.Y. Moon, and C.Y. Lee. 2003. Quantification of polyphenolics and their antioxidant capacity in fresh plums. J. Agr. Food Chem. 51:6509-6515, https://doi.org/10.1021/jf0343074.

Kumar, D., D.S. Mishra, B. Chakraborty, and P. Kumar. 2013. Pericarp browning and quality management of litchi fruit by antioxidants and salicylic acid during ambient storage. $\mathrm{J}$. Food Sci. Technol. 50:797-802, https://doi. org/10.1007/s13197-011-0384-2.

Luo, Z., C. Chen, and J. Xie. 2011. Effect of salicylic acid treatment on alleviating postharvest chilling injury of 'Qingnai' plum fruit. Postharvest Biol. Technol. 62:115-120, https://doi. org/10.1016/j.postharvbio.2011.05.012.

Maan, A.A., Z.F.R. Ahmed, M.K. Iqbal Khan, A. Riaz, and A. Nazir. 2021. Aloe vera gel, an excellent base material for edible films and coatings. Trends Food Sci. Technol. 116:329-341, https:// doi.org/10.1016/j.tifs.2021.07.035.

Maskan, M. 2001. Kinetics of colour change of kiwifruits during hot air and microwave drying. J. Food Eng. 48:169-175, https://doi.org/ 10.1016/s0260-8774(00)00154-0.

Mohamed, S.A., M.A. Awad, and A.D. Al-Qurashi. 2014. Antioxidant activity, antioxidant compounds, antioxidant and hydrolytic enzymes activities of 'Barhee' dates at harvest and during storage as affected by pre-harvest spray of some growth regulators. Scientia Hort. 167:91-99, https://doi.org/ 10.1016/j.scienta.2014.01.003.

Molamohammadi, H., Z. Pakkish, H.-R. Akhavan, and V.R. Saffari. 2020. Effect of salicylic acid incorporated chitosan coating on shelf life extension of fresh In-Hull Pistachio fruit. Food Bioprocess Technol. 13:121-131, https://doi. org/10.1007/s11947-019-02383-y.

Moreno-Escamilla, J.O., E. Alvarez-Parrilla, L.A. de la Rosa, J.A. Núñez-Gastélum, G.A. GonzálezAguilar, and J. Rodrigo-García. 2018. Effect of elicitors in the nutritional and sensorial quality of fruit and vegetables, p. 71-91. In: M.W. Siddiqui (ed.). Preharvest modulation of postharvest fruit and vegetable quality. Academic Press, Cambridge, MA.

Mortazavi, S.M.H., F. Azizollahi, and N. Moallemi. 2015. Some quality attributes and biochemical properties of nine iranian date (Phoenix dactylifera L.) cultivars at different stages of fruit development. Int. J. Hort. Sci. Technol. 2:161-171, https://doi.org/10.22059/ijhst.2015.56433.

Panahirad, S., R. Naghshiband-Hassani, B. Ghanbarzadeh, F. Zaare-Nahandi, and N. Mahna. 2019. Shelf life quality of plum fruits (Prunus domestica L.) improves with carboxymethylcellulosebased edible coating. HortScience 54:505-510, https://doi.org/10.21273/hortsci13751-18.

Petriccione, M., F. De Sanctis, M.S. Pasquariello, F. Mastrobuoni, P. Rega, M. Scortichini, and F. Mencarelli. 2015a. The effect of chitosan coating on the quality and nutraceutical traits of sweet cherry during postharvest life. Food Bioprocess Technol. 8:394 408, https://doi.org/ 10.1007/s11947-014-1411-x.

Petriccione, M., F. Mastrobuoni, M.S. Pasquariello, L. Zampella, E. Nobis, G. Capriolo, and M. Scortichini. 2015b. Effect of chitosan coating on the postharvest quality and antioxidant enzyme system response of strawberry fruit during cold storage. Foods 4:501-523, https:// doi.org/10.3390/foods4040501.

Rahman, M., J.A. Mukta, A.A. Sabir, D.R. Gupta, M. Mohi-Ud-Din, M. Hasanuzzaman, M.G. Miah, M. Rahman, and M.T. Islam. 2018. Chitosan biopolymer promotes yield and stimulates accumulation of antioxidants in strawberry fruit. PLoS One 13:e0203769, https://doi.org/ 10.1371/journal.pone.0203769.

Rastegar, S., M. Rahemi, A. Baghizadeh, and M. Gholami. 2012. Enzyme activity and biochemical changes of three date palm cultivars with different softening pattern during ripening. Food Chem. 134:1279-1286, https://doi.org/ 10.1016/j.foodchem.2012.02.208.

Romanazzi, G., E. Feliziani, M. Santini, and L. Landi. 2013. Effectiveness of postharvest treatment with chitosan and other resistance inducers in the control of storage decay of strawberry. Postharvest Biol. Technol. 75:24-27, https://doi. org/10.1016/j.postharvbio.2012.07.007.

Romanazzi, G., E. Feliziani, and D. Sivakumar. 2018. Chitosan, a biopolymer with triple action on postharvest decay of fruit and vegetables: Eliciting, antimicrobial and film-forming properties. Front. Microbiol. 9:2745, https://doi.org/ 10.3389/fmicb.2018.02745.

Ruiz-García, Y. and E. Gómez-Plaza. 2013. Elicitors: A tool for improving fruit phenolic content. Agriculture 3:33-52, https://doi.org/10.3390/ agriculture 3010033 .

Sayyari, M., M. Babalar, S. Kalantari, M. Serrano, and D. Valero. 2009. Effect of salicylic acid treatment on reducing chilling injury in stored pomegranates. 
Postharvest Biol. Technol. 53:152-154, https:// doi.org/10.1016/j.postharvbio.2009.03.005.

Shafiee, M., T.S. Taghavi, and M. Babalar. 2010. Addition of salicylic acid to nutrient solution combined with postharvest treatments (hot water, salicylic acid, and calcium dipping) improved postharvest fruit quality of strawberry. Scientia Hort. 124:40-45, https://doi.org/10.1016/j.scienta. 2009.12.004.

Sharif, R., M. Mujtaba, M. Ur Rahman, A. Shalmani, H. Ahmad, T. Anwar, D. Tianchan, and X. Wang. 2018. The multifunctional role of chitosan in horticultural crops; a review. Molecules 23: 872, https://doi.org/10.3390/molecules23040872.

Shen, Y. and H. Yang. 2017. Effect of preharvest chitosan-g-salicylic acid treatment on postharvest table grape quality, shelf life, and resistance to Botrytis cinerea-induced spoilage. Scientia Hort. 224:367-373, https://doi.org/10.1016/j.scienta. 2017.06.046.

Shiri, M.A., D. Bakhshi, M. Ghasemnezhad, M. Dadi, A. Papachatzis, and H. Kalorizou. 2013. Chitosan coating improves the shelf life and postharvest quality of table grape (Vitis vinifera) cultivar Shahroudi. Turkish J. Agr. 37:148-156, https://doi.org/10.3906/tar-1101-1671.
Sohail, M., M. Ayub, S.A. Khalil, A. Zeb, F. Ullah, S.R. Afridi, and R. Ullah. 2015. Effect of calcium chloride treatment on post harvest quality of peach fruit during cold storage. Int. Food Res. J. 22:2225-2229.

Tian, S., Y. Wan, G. Qin, and Y. Xu. 2006. Induction of defense responses against Alternaria rot by different elicitors in harvested pear fruit. Appl. Microbiol. Biotechnol. 70:729-734, https://doi.org/10.1007/s00253-005-0125-4.

Vayalil, P.K. 2012. Date fruits (Phoenix dactylifera Linn): An emerging medicinal food. Crit. Rev. Food Sci. Nutr. 52:249-271, https://doi.org/ 10.1080/10408398.2010.499824.

Vayalil, P.K. 2013. Bioactive compounds, nutritional and functional properties of date fruit, $\mathrm{p}$. 285-303. In: M. Siddiq, S.M. Aleid, and A.A. Kader (eds.). Dates: Postharvest science, processing technology and health benefits. 1st ed. Wiley-Blackwell, Hoboken, NJ.

Velioglu, Y.S., G. Mazza, L. Gao, and B.D. Oomah. 1998. Antioxidant activity and total phenolics in selected fruits, vegetables, and grain products. J. Agr. Food Chem. 46:4113-4117, https://doi.org/ $10.1021 / \mathrm{jf} 9801973$.

Wang, L., S. Chen, W. Kong, S. Li, and D.D. Archbold. 2006. Salicylic acid pretreatment alleviates chilling injury and affects the antioxidant system and heat shock proteins of peaches during cold storage. Postharvest Biol. Technol. 41:244-251, https://doi.org/10.1016/j.postharvbio.2006.04.010.

Wang, Y.-Y., B.Q. Li, G.Z. Qin, L. Li, and S.P. Tian. 2011. Defense response of tomato fruit at different maturity stages to salicylic acid and ethephon. Scientia Hort. 129:183-188, https:// doi.org/10.1016/j.scienta.2011.03.021.

Wu, H.C., H.M. Chen, and C.Y. Shiau. 2003. Free amino acids and peptides as related to antioxidant properties in protein hydrolysates of mackerel (Scomber austriasicus). Food Res. Int. 36:949957, https://doi.org/10.1016/S0963-9969(03)00 104-2.

Xylia, P., A. Chrysargyris, Z.F.R. Ahmed, and N. Tzortzakis. 2021. Application of rosemary and eucalyptus essential oils and their main component on the preservation of apple and pear fruits. Horticulturae 7:479, https://doi.org/10.3390/horti culturae 7110479 .

Zhang, Y., K. Chen, S. Zhang, and I. Ferguson. 2003. The role of salicylic acid in postharvest ripening of kiwifruit. Postharvest Biol. Technol. 28: 67-74, https://doi.org/10.1016/S0925-5214(02) 00172-2. 